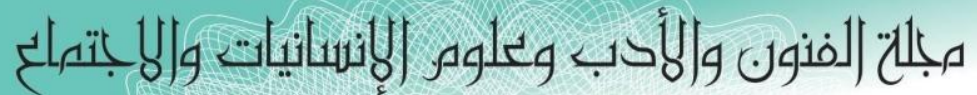

Joumal of Arts, Literature, Humanities and Social Sciences

ISSN online: 2414 - 3383

العدد (44) أكتوبر 2019

ISSN print: 2616 - 3810

Volume (44) October 2019

\title{
Women Oppression and Challenge of Patriarchal System
}

\author{
Iman Neamah Jasim \\ Pendidikan Sultan Idris University (UPSI), Tg. Malim, Perak, Malaysia \\ E-mail: flamingo_e@yahoo.com \\ Lajiman Bin Janoory \\ Pendidikan Sultan Idris University (UPSI), Tg. Malim, Perak, Malaysia
}

\begin{abstract}
This paper deals with the resistance of the patriarchal system in Palestinian society in Khalifeh's The Image, The Icon and The Convent. In general, the paper is going to discuss the resistance's women to the patriarchal system in this novel. Actually, women fall victims of gender oppression. They suffer from the sequences of patriarchy and its effect upon woman's life. The novel specifically hinges of Palestinian society portrayed in the plots. The women of this society deal with various types of gender oppression. Women are the most influenced by the patriarchal system because they lose their freedom. As a result, they lead a hard life created by the dominated men who practice oppression against them. As such, the paper will accurately study women's agony in order to accentuate the essence of gender oppression in the course of the novels' plots.
\end{abstract}




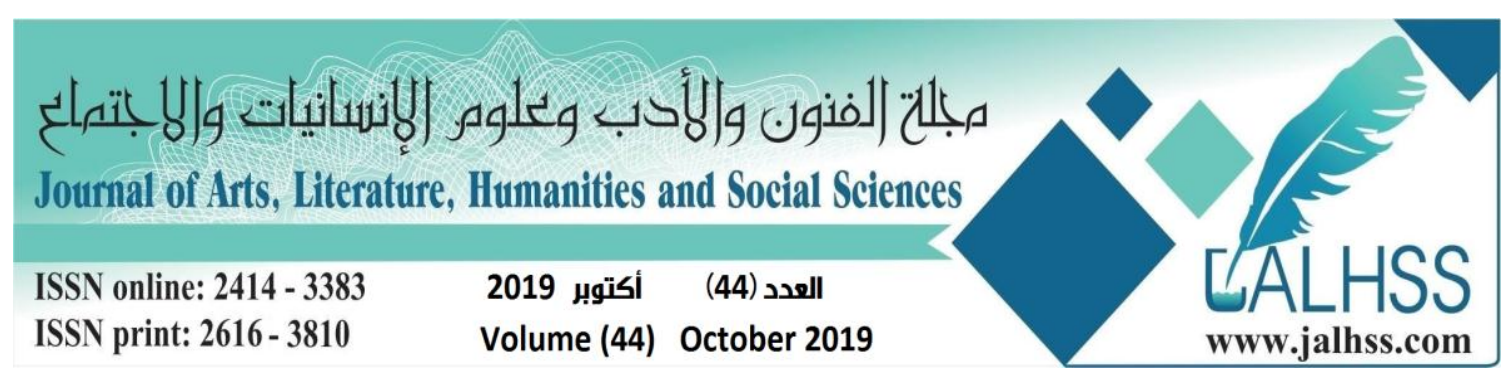

\section{Introduction}

Patriarchy is a clear topic in Khalifeh's works. In her novels she reveals the agony of Palestinian women by her patriarchal society which abuse them for various purposes, including housework. However, most of her female characters are often portrayed as victims of Jewish colonists who influence their lives. In other words, Jews practice oppressive colonialism on Palestinian society, making its men oppress women. Therefore, the oppression of women begins when men are marginalized. This is generally argued as gender oppression (Johnson, 2007).

As a matter of fact, gender oppression results from inequality between women and men and embodies women as victims of dominating men who put them under their control. Therefore, women are always portrayed as being inferior to dominate men. They exploited them only to fulfill their needs (Manne, 2019). In this regard, Khalifeh's illustration of patriarchy is characterized by gender oppression and how Palestinian women resist such oppression. Patriarchy, in Khalifeh's point of view, approaches Palestinian women in lower rank in their society. They do not match or mimic men's position in the patriarchal society. As a matter of fact, society constriction plays a vital role in determining the gender measurements of patriarchal gender oppression in Khalifeh's works. Society constriction is undoubtedly the most influential factor in the subordination of women (Johnson, 2007).

According to Manne there are four obvious factors that result in the treatment of gender oppression. First, inherited traditions are the main foundation of the patriarchal system that women must resist. The Palestinian society is conservative. That is, it inherits its social and cultural perception of women from ancestors. These ancestors insist that women are considered inferior to men. They should not participate in the social and political affairs of society. It is controlled only by men who dictate what women should and should not do. Being so, patriarchy is inherited from form fathers and is passed on to future generations that continue to consider women inferior to men (Manne, 2019). Second, economics is a vital characteristic of the Palestinian society which pays great attention to labor. This is because the Palestinian people suffered and continue to suffer from oppressive colonial conditions.

Colonialism effect on their economic status. Some families, exploit their daughters in labor in order to earn enough income to compensate for the loss of their property that demolished by the colonists. Therefore, women work hard in order to support their families. They also encourage them in their struggle against the Jewish oppression. Third, domestic duties are considered as another factor of Palestinian patriarchal society. In this society, the traditional imposes on men and women different roles because they differ from each other. On the one hand, men work and earning expenditure of the family, but women are bearded responsibility for the whole domestic affairs. For example, they raise children, cook food, prepare the house's and husband needs and take care of their husband's parents. Women are required to do all these duties alone without any real help with their men because the traditions of 


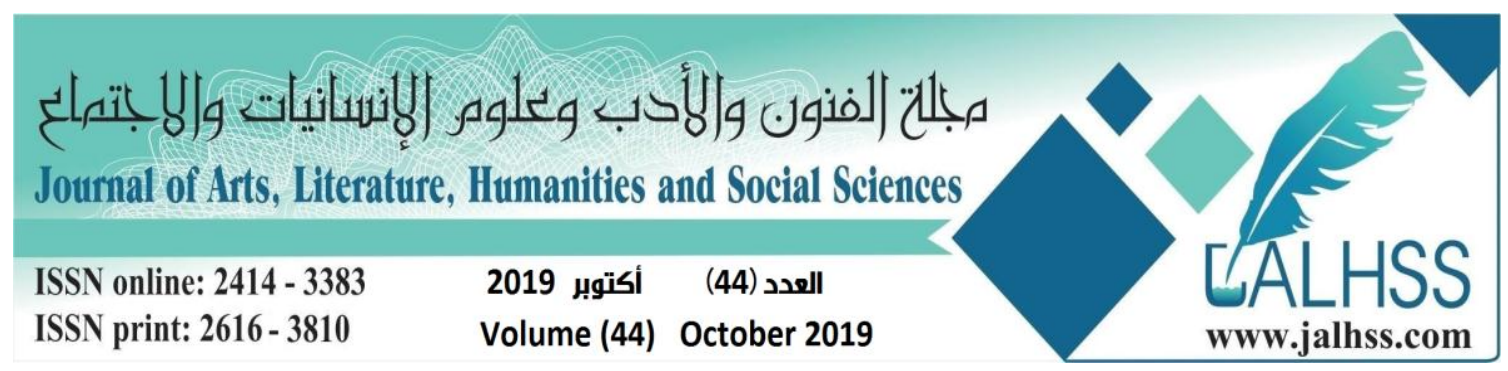

society are flawed men participate wives in domestic affairs. The fourth factor is the culture of shame. To clarify, the Palestinian society considers women's wrong doings, like interacting with men and having them as friends. This action is utterly shameful. Therefore, families try to keep their girls away from these interactions to save their reputation, or else, their women would bring them disgrace and dishonor (Manne, 2019).

\section{Methodology}

The focus of the article will be on Sahar Khalifeh's The Image, The Icon and The covenant, and the general formwork will be postcolonial feminism. We will use the gender oppression concept to be applied. The concept is going to explain for the sake of description of its methodological application to analyze the selected novel. The application of postcolonial feminism of this novel will explore this patriarchal power which was worked to dominate and control on the woman's life. Dominated men made most of the women of the patriarchal society to be enslaved, exploited and oppressed. The article will explain this concept and shed light on the theoretical argumentations about it, on a deeper level.

Judith Lorber will be depended on so as to provide a foreground of the theory about postcolonial feminism for exploration of the gender oppression, and the obsolete social pressures influence of the selected novel's protagonists. In portraying their struggles inside the general plight of the Palestinian society, Khalifeh condemns both the colonial military forces and the similarly oppressive patriarchal rules. In addition, so as to explain the problems that the protagonists under patriarchal system are facing, these concepts will be introduced. This paper also concluded that Khalifeh's Palestinians women characters reflect the sufferings in the patriarchal society. Throughout their challenge, it can be concluded that Palestinian women are able to resist patriarchy and try to liberate their selves from these traditional values.

\section{Literature review}

Feminist patriarchy is a matter of ongoing debates about the superiority of strong masculinity over women in Palestinian society. Khalifeh supports her fictional feminist characters to defend the active role of females in society in order to pave the way for women's resistance. She follows rhetorical details of the ideological qualities of a feminist perspective in her works (Priyanka \& Koudur, 2016). Feminist attitudes must believe in gender equality, such as males and females. Men should not commit gender-based crimes, such as rape, marginalization and deprivation. In this regard, neither males nor females should exclude each other. Both should be responsible for upgrading their society by avoiding prejudice or gender bias against each other (Manne, 2019). As such, the typical impression of a persecuted woman in the works of Khalifeh refers to the social inferiority that must be restored and made equal to men without discrimination on the basis of sex.

In Gender Inequality: Feminist Theories and Politics, Judith Lorber (2012) discusses the same topic. She says that women are socially persecuted to represent the 


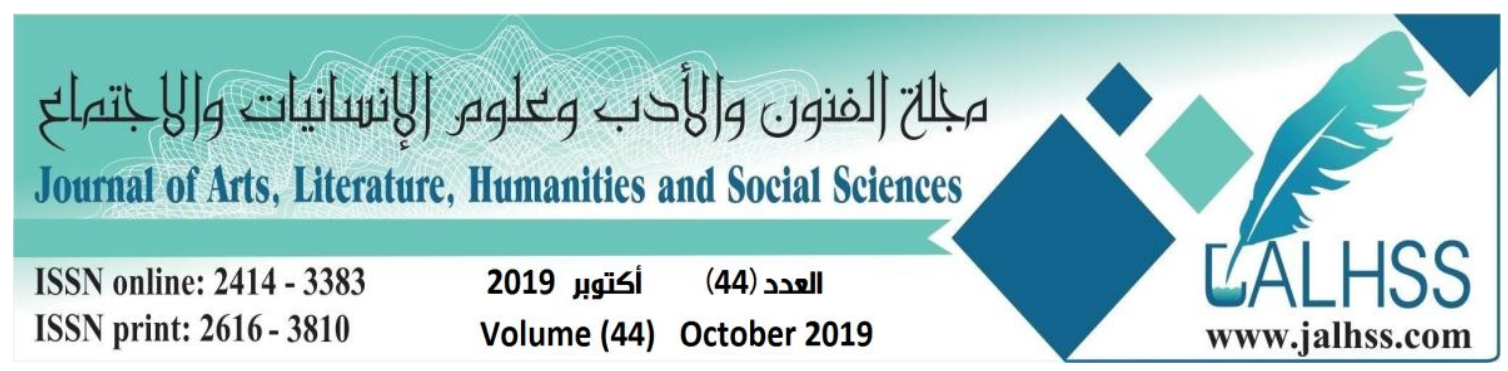

characteristics of the patriarchal system that oppresses women. In this way, women are subordinated to men in patriarchal societies because men are the main dominant sex; male dominance arises from a society that elevates men over women: "men are the actors' women the reactors. Men thus are the first sex, women always the second sex. Man's dominance and women's subordination is not a biological phenomenon, but a social creation" (p. 3).

Khalifeh also discusses the negative sequence of female-only exploitation of business. They must be treated as human beings. Here, human elements are a clear theme of patriarchy in her works. Women should be treated as human beings. Accordingly, class plays an important role in posing problems for females. It does so, describing class and sex in sync with the culture. Females are persecuted by male power in the light of patriarchal culture because men make that oppressive culture and not vice versa (Farrugia, 2019). Thus, Khalifeh perceives women only to stimulate men's recognition of women as human beings because they have long been bound by inherited cultural traditions. This is another sign of women's resistance. These traditions pave the way for a negative social phenomenon, such as virginity issues and raising children according to social traditions. In this sense, the treatment of women is extremely harsh in traditional patriarchal cultures in most of the Khalifa's work (Priyanka \& Koudur, 2018).

In her novels, Khalifeh raises many implicit questions about gender, especially in Palestine. One of these questions is feminist experiences. Feminist experiences have deep roots in patriarchal social traditions. They are directly related to inherited cultural considerations by avoiding the status of women in repressive categorizations and classifications (Farrugia, 2019). In addition, feminist connotation has implications for females in Khalifeh's work. These repercussions are institutionally determined, and therefore, ideologically determined by allocating feminist disparity to a persuasive cultural skill to promote women's rights to equality with men. In this regard, cultural models are the symbolic representation of real females in society. This is because feminism is one of the most resonating themes in society. The portrayal of women's suffering and hardship is a key question raised by Khalifeh personalities who deal with the issue of female subjectivity; and how women can be strong in patriarchal societies. The suffering of women can also provide new perceptions of the female attitude and possible upgrading. Therefore, the female literary figures of the Khalifeh are exemplary models that provide a compelling and attractive vision for women in real Palestinian society (Johnson, 2007). Lorber (2012) argues that gender oppression is the essence of gender inequality; society views men and women differently because men and women are naturally different from one another: "gender inequality is built into the structure of the gendered social order because the two statuses - women and men - are treated differently and have significantly different life chances" (p.9). 


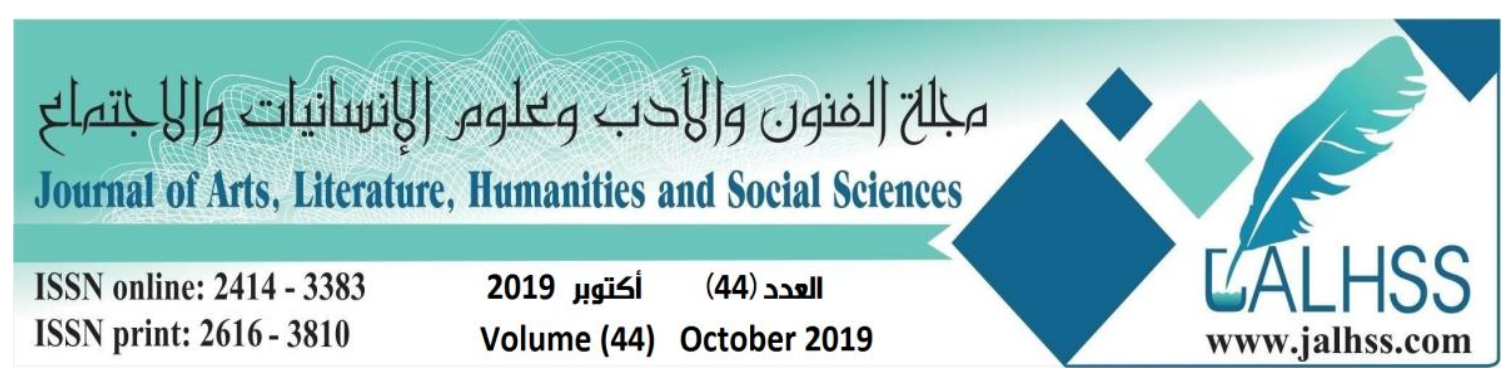

In this regard, Khalifeh portrays the harsh conditions of the woman and her serious attempt to get rid of her male oppression. The perception of women in difficult circumstances will lead to possible solutions to their atrocious conditions. These conditions result from patriarchal society that does not fulfill the needs of women and participates in their marginalization. However, women can be strong enough to support their families and challenge their traditional appreciation as inferior to males. Thus, patriarchal culture is one possible way of revealing the immense ability of women to change their negative position in society. The harsh conditions of women, resulting from the marginalization of men, lead Khalifeh to focus on the inferiority of women in her work. Similarly, its work was mostly explained by a critical condemnation of the Patriarchate. They often seek to abolish patriarchy to provide women with a good life. This would help women avoid patriarchal superiority and underestimate their advantages as human beings (Farrugia, 2019).

Therefore, the Patriarchate is accurately depicted in Khalifeh's novels. In an obvious way, it gives its women a voice to oppose oppressive masculine practices against them. For example, they challenge patriarchy by seeking autonomy (AbuManneh, 2016). They try to fulfill their needs away from supporting men. They can work, learn and do their personal affairs without relying on men. Khalifeh deals with these patriarchal issues by recognizing women in literary plot. In so doing, it accurately presents factual accounts of Palestinian patriarchal society and how women are perceived. Moreover, she deals with women's issues in different social perspectives in order to give women a strong and expressive voice for equality with men. In the long run, they can live like men and do the same social tasks away from gender-based persecution and marginalization. This is the representative characteristic of the human features of Khalifeh's narrative with regard to the patriarchate, that is, the novels are a vivid and subversive condemnation of the patriarchy that destabilizes women and distorts the potential social balance between men and women. (AbuManneh, 2016).

Lorber (2012) confirms that patriarchy plays a marginal role leading to the persecution of hatred of women. She says patriarchy creates and encourages genderbased persecution that supports men's repressive control over women's personal affairs, such as emotions and related reactions.: "the social encouragement of male aggression and their patriarchal entitlement encourages the violent potentialities of men's control of women's bodies, sexuality, and emotions" (p. 15).

Moreover, Khalifeh emphasizes the role of females in society in resisting this type of women. The young woman lives in a patriarchal society where females remain either scapegoats or passive human beings. They only play a marginal role. They may not share the affairs of men. This is the moral aspect of the Patriarchate in most of Khalifeh's work (Nazareth, 1980). To establish feminist ethical principles, moral significance can be revealed by changes in the literary perception of reality in which women are treated as inferior to men. Therefore, it incorporates implicit influential insights into the work in order to emphasize the need to look at women and their relative problems. 


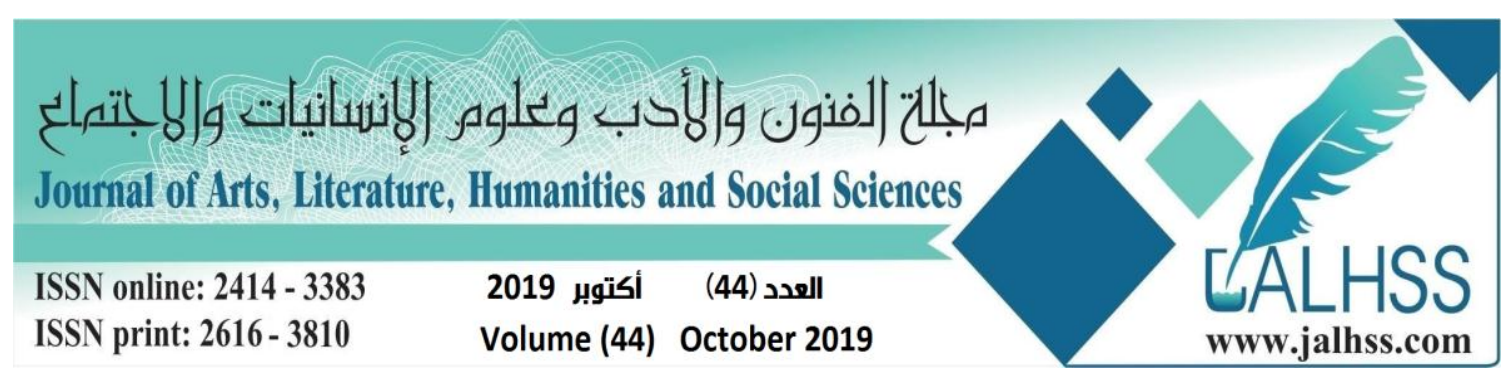

Over time, their problems will be solved when patriarchal cons are minimized (Criado, 2019). In this regard, women's problems are diverse and various in Khalifeh's work. There are many social problems that marginalize women and place them in a narrow range of gender-based persecution. Khalifeh addresses these problems to promote a possible way to save women from patriarchal and gender restrictions (Nazareth, 1980).

One of these problems is honor killings. Patriarchal societies are very strict with women's mistakes. Committing adultery, for example, is never forgiven. Women are not allowed to modify their mistakes. Such action is treated as a fundamental sin. The only way to get rid of this sin is to kill women (Criado, 2019).

Khalifeh deals with these problems in most of her novels to inform the reader of the complex patriarchal mentality that does not empathize with women's problems. Therefore, moral authority is lost in such societies. The only social privilege is granted to men who represent the mainstream; while women's problems are deemphasized and not given equal impact. Legitimate is controlled by men who decide the full social affairs of their people, including women. Consequently, Khalifeh treats patriarchy as a social ideology that tries to provide a rational justification for masculine dominance attributed to natural innate inequalities between women and men. At the same time, she calls for logical opposition to that domination; she explicitly calls for gender equity rather than gender persecution. She illustrates how the gender role is played mainly by men who try to gain tremendous power to influence the whole society. However, she depicts the anti-feminist force that resists the masculine trend to prove women's personality to emulate the sovereignty of men. As a result, women's resistance is an anti-patriarchal thesis that produces genderbased persecution and marginalization. Khalifeh's works are full of these coherent themes of gender persecution in order to provide viable solutions through women's resistance (Kristen, 2014). Lorber (2012) argues that gender oppression involves constant communication between men and women. In this connection, the entire community supports men because they are superior to the women. This superiority makes men more privileged and socially better than women:

Patriarchy can be found wherever women and men are in contact with each other, in public life as well as in the family. It is very hard to eradicate because a sense of their superiority to women is deeply embedded in the consciousness of most men and is built into the structures of society. This privilege has come to be known as the patriarchal dividend. (P. 74)

Lorber (2012) says that women bring a bad omen to their male-dominated communities. Accordingly, they should be marginalized and oppressed by men. Patriarchy and its production of gender repression is patrilineality. As the terminology implies, patrilineality means that men are entitled to inherit power from their fathers 


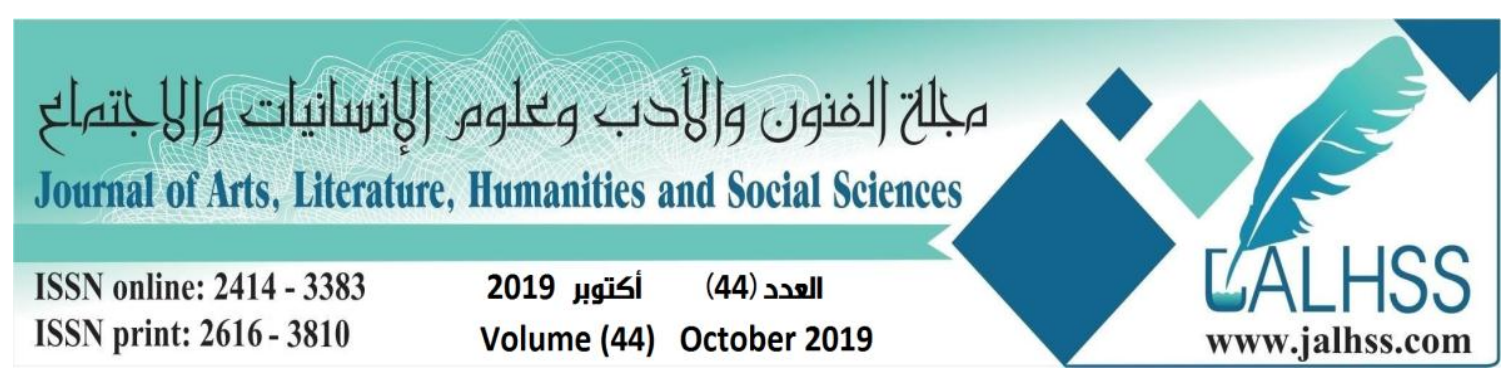

rather than women. They have the right to control the family, their children and property; women are almost excluded from this privilege. They only follow male orders and authority. Moreover, the Patriarchate does not allow women to participate in political affairs. Only men are political decision makers. That being the case, the representative concept of patriarchy is the marginalization of women, which is gender oppression itself. The result will be unfair because women will face obstacles in their determination to evolve and prove their self as human beings. They could not fulfill their will; thus, they became victims of the patriarchy. In this sense, patriarchy becomes an anti-humanist ideological system that surpasses women's affairs; instead, women's rights in childbirth are undermined. It does not provide a fair opportunity for women to improve their social status because they are fully controlled by men (Farrugia, 2019).

On the other hand, Khalifeh's work seriously envisages these gender issues for the purpose of emancipating women. To illustrate this, she criticizes the patriarchal that hinders women's ability to emulate men. Moreover, she opens new horizons for women to recognize their power and rights in deciding their independence and decision-making (Kristen, 2014). Lorber argues that patriarchy is the underlying cause of gender oppression; it creates desperate conditions of women's lives. To improve the hard conditions of these women, she says, economic, family and kinship must interact and protect her from gender-based persecution: "women are living in dire conditions. To redress their situation, whole economic structures and family and kinship systems need to be overhauled" (p. 69).

\section{Data Analysis}

Sahar Khalifeh's The Image, The Icon and the Covenant deals with patriarchy and its challenge through the experiences of four women. The novel indicts the atrocious attitudes towards women in their male-dominated society. The first woman is Um Ibrahim. She suffered from her patriarchal family that prefers to raise many children. She is a victim of traditions society. Her dilemma begins when she loses her son who died in the awful conditions under colonial subjugation. She got deeply grievous about him. Thus, she suffered bleeding that prevented her from giving birth. Her husband abandons her to marry another young woman gave many sons. This is an obvious indication of how patriarchal men like raising children to order to ensure their inheritance when they die. In addition, having many children is a symbol of strict men who insist on having children:

So we were reduced to being a small family, too small for an Arab man who wanted a good stock and many heirs. This was his excuse for remarrying. He used to say, 'I want a woman who gives birth to men (p. 20). 


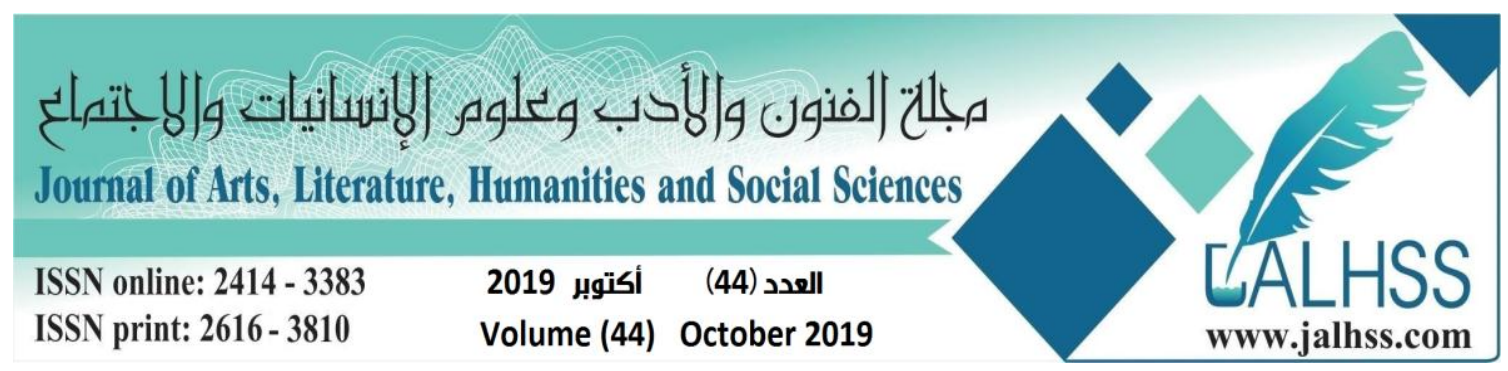

His eagerness to marry another woman and young is a kind of an exclusion of Um Ibrahim. She became deserted because she no longer had a husband. This desertion is a persecution of women. In patriarchal societies, women are abandoned in order to have sons; or as her husband explains it: "I need a male descendant to carry my name" (p. 21). In this sense, he was left her just because he wanted sons carrying his name. She became alone, no one to support her. Her inability to give birth deprived her from her husband's support and care. He insists on marrying another woman to have many sons for two reasons: carrying his name and inheritance, and these things brought him respect in his patriarchal society. However, she did not become weak. She raised her children and lived as father and mother for them. She remained strong and did not give up to her subjugation at the hands of her patriarchal traditions. Lorber (2012) discuses that men in the patriarchal society follow the social traditions to establish their control over the family members, especially their women:

Gender is a social status and a personal identity, as enacted in parental and work roles and in relationships between women and men. Through the social processes of gendering, gender divisions and roles are built into the major social institutions of society, such as the economy, the family, the state, culture, religion, and the law-the gendered social order. Woman and man are used when referring to gender. (P. 8)

In other words, the oppression of women is the product of male prejudice and prejudice against women who are exploited only as tools to fulfill men's needs and desires. Abraham's mother, then, is a kind of woman who is harassed by their men.

Sara, Ibrahim's sister also suffers from patriarchal system. She was thirty years old. In traditional society, a woman's will is constrained. She could not choose her husband, particularly when she gets older. The age of marriage for women is usually the second decade of her life. Ibrahim feels sympathy with his sister who is obliged to marry a man whose she does not meet him before: "My sister had nothing to say because she was not a man or close to one" (p. 21). Sara and her fiancé do not know each other before. Marriage is proposed through photos or telephone conversations. Ibrahim does not accept their marriage this way and tries to help his sister, but she cannot oppose her father's wish. At this stage, excessive male oppression of women lies in the fact that women are deprived of their will. They couldn't choose their husbands. They don't even have any ideas about their future with their husbands. So, Sarah's case is an example. Her marriage is planned by phone, or as Ibrahim describes it: "Everything was arranged through the photo: the engagement and the marriage" (p. 24). This unexpected marriage destroys her future. She does not know whether she will live a good life or not. Thus, her future seems scary and bleak. In this regard, patriarchal authority imposes the hardship of life on women. It does not allow them self-respect or free will. Khalifeh imagined this misribale life through the eyes of the narrator who wonders about Sarah's life with her husband. She may not be satisfied with her life because her husband will resemble her father in terms of patriarchal bias 


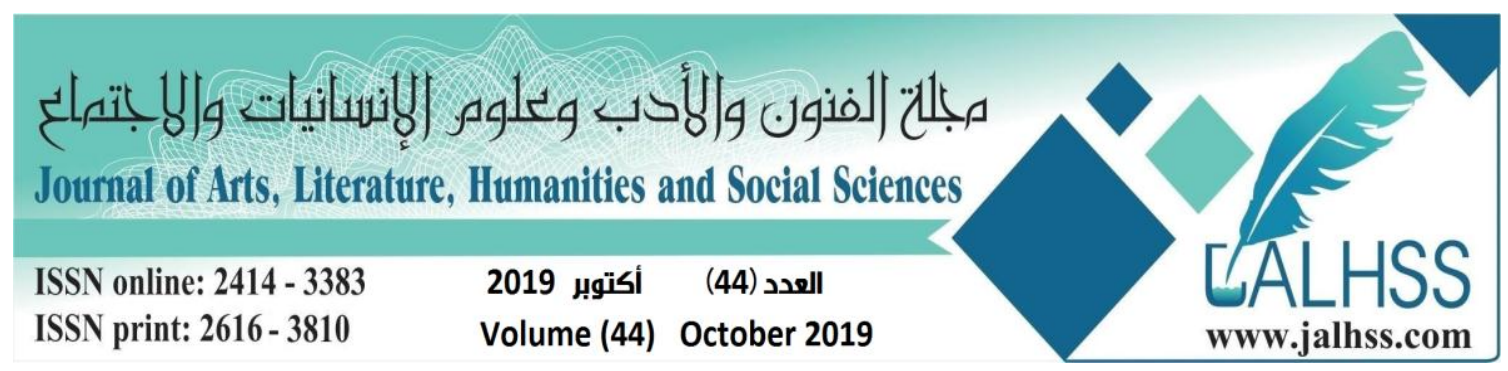

against women. In addition, he may have satanic children bothering her. It is true at this point that husbands, in patriarchal societies, oppressively ask their wives to care of their children because women are only required to practice domestic life. The narrator, in Khalifeh's The Image, The Icon and the Covenant, thinks of these conditions in these sentences:

I looked at her and felt sad, worrying about her future. What if things don't turn out to be the way she expects? What if the man turns out to be like my father! What would she do if he divorces her? Would he like her? How would she deal with his children if they turned out of truly be devils? (P. 25).

In light of this quote, Sarah is treated bitterly by her patriarchal family. Her father was worried about her future because she was late in marriage and could become a spinster. Accordingly, he decided to marry his daughter with a widow even though Sarah did not know him before. She knew it only through photo: "She doesn't know him. What are the chances for a successful phone marriage? All she saw of this man was his picture" (p.25). However, Sara rejects this marriage. She refuses to marry a widower with many children. But, she lives in a patriarchal family; and she does not have another choice except for accepting this marriage. When she imagines her life with him, she compares her life like an exile with that man. She will live in a desert, not in a family. She tries to tell her father about these feelings as follows: "I'll be exiled to the desert" (p. 24). This fact is attributed to her traditional marriage through pictures. Her family does not give her another chance to wait for other marriage proposals; If she rejects this picture she will replace another one as a result, her future life will be based on a picture. She will live in the unknown. She might be unlucky with her husband. For this reason, she rejects marriage proposals. However, she got older. She is more than thirty years old. At this age, a woman is considered spinster in patriarchal society. Moreover, she has no choice to accept or reject her marriage. She is only required to accept the marriage, her family wishes to organize. Thus, she has no will to decide her marriage. She must comply with her family's order regarding marriage. In contrast, she refuses her traditional marriage; her father tells her that she will be forcibly married because she has no other choice.

In the case of marriage, women have no real role in choosing their husbands and neither has heard their objections or rejected them. Often, the decision to marry is made by the dominant men in the family. The decision to marry is an agreement between the two families which is often close. As such, the Father embodies the patriarchal bond. He plays an influential role in Sarah's life. He forces her to marry a man. He chose her husband. All she asks to accept is whether she knows him or not. Here, the oppression of women corresponds to Sarah's example. Although she has the right to accept or reject her marriage, she is denied by her decision. The reason behind her bitterness, life is attributed to her Eastern patriarchal society. She is a victim of her father's traditional view of life regarding his daughter, or as Lorber (2012) puts it, 


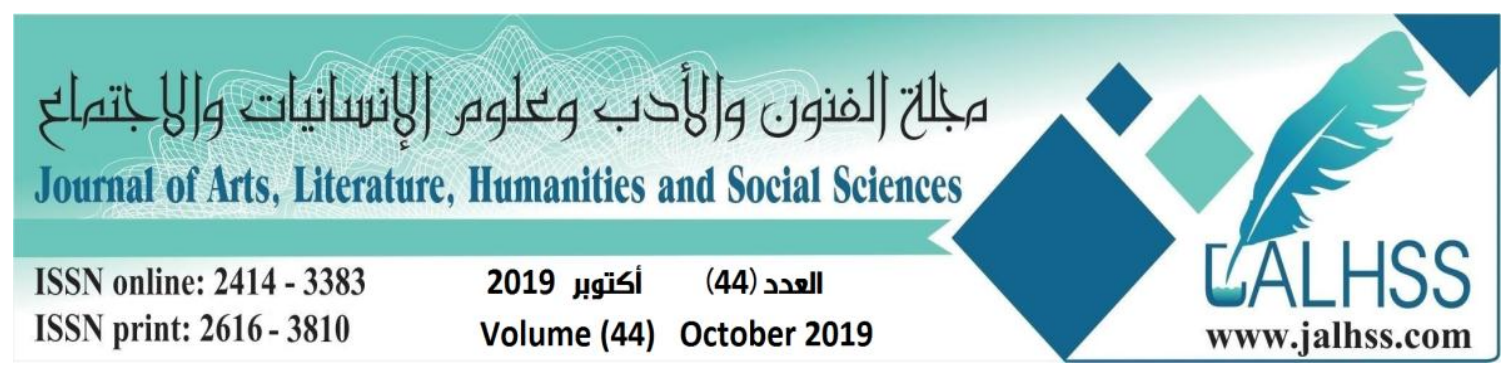

women, in patriarchal societies, perform their "father's Orientalist inclinations" (p. 73).

Mariam is another victim of patriarchy. The novel defines her as a welleducated woman. This is due to the fact that she lived in an open society in the life of the Diaspora. She emigrated to Brazil with her family. At the beginning of the novel, she was present as a multilingual woman living in a large villa. She was a rich and educated woman. This means they have a good cultural background. Mariam is the most important figure; she is favored by other people as the main character of the story, or the hero of the story. In Brazil, her brothers took her and forced her to live in a monastery. This is the first symbol of its suppression at the hands of its fellow parents. They put her in the convent because they wanted her to live away from Brazilian liberal society: "Mariam has enough troubles with her seven brothers watching over her like guards. She is all alone, and if it weren't for the priest, she would be in a convent by now" (p. 16). This compares to the story of the five giants who oppress the innocent Snow White. Her brothers love the seven giants and she loves Snow White. Her brothers decide to return her to Palestine. They took her with her mother to live in their motherland. In doing so, they secure her safe living outside Brazilian society. They forced her to return to Palestine and lived there.

Mariam returns. Yet, she falls in love with Ibrahim. She is Christian and Ibrahim is a Muslim. Therefore, society rejects this kind of love. Therefore, she became confined by her brothers and society. Ibrahim describes his first meeting with her: "That was my first hug with a woman other than my mother, but was I the first man she had hugged" (p. 41). Her relationship with Abraham is destroyed. He is jealous because she told him about her past love for the priest in Brazil. He becomes suspicious if she still loves the priest or forget him. In this regard, turn into a victim of jealous eastern man. He suspects and asks himself if she loves him: "she told me her story, the story of her exile.... She had fallen in love with a priest in that country and had almost caused him to leave the priesthood" (p. 42). Despite his love for her, Ibraham leaves her alone. Jealousy overwhelmed him. Consequently, she is oppressed by his sensitive eastern feelings towards her. Disturbs her life, even in dreams. Ibrahim became a nightmare for her. When she is alone, she remembers her relationship with him in the Covent. It was like taboo to love a man without marital affairs. This is the typical response of patriarchal society in such a relationship. Lorber (2012) says that this response is a way of "transcending tribal and family loyalties" (p. 119).

Mariam's brothers deceived her that she will be happy and marry a man and live with him peacefully in her country. Her life became like prison: "They said that I was growing up and that the home country was better for me. I would marry like other girls, have children, and forget him" (p. 45). She unwillingly returned to her homeland Palestine. She did not know anything about it. Yet, she was forced. In homeland, she suffered at the hands of her lover compatriot, Ibrahim, who said that 


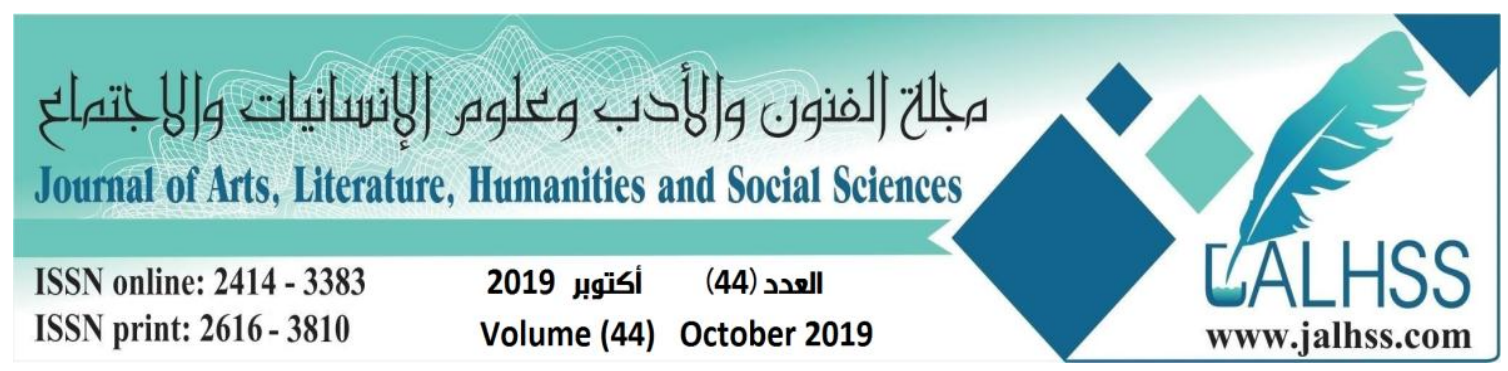

"Mariam was not mine after all" (p. 46). He is poisoned by his jealousy. When she told him about her last lover, he became angry with jealousy. He decided to avoid them to get rid of jealousy and anxiety. He tried to save himself from drowning and obsessed with her love. Mariam is amazed. Did not know the cause of jealousy and ill-treatment. Ask him about the motives of jealousy: "Did I do something wrong? What is it? ... Because I trusted you with my secrets" (p. 47). He is responsible for her suffering. She is innocent. However, Ibraham's treatment exemplifies his patriarchal reactions. He wants to suppress her like his mother and sister Sarah: "But you, what are you? A repressed adolescent, an eastern man, a hypocrite. You want her to be like your mother and like Sarah? You're looking for your mother and for Sarah in her" (p. 47).

Ibrahim justifies his persecution for the fact that they are from different cultural backgrounds. Moreover, he still doubts her emotional tendency to her former love for the priest. He feels she didn't like him for himself, but she used it as a decoy. He wanted to know whether she really loved him or was just a substitute for the priest. All these doubts, he had about her past relationship with the priest made him feel that he hated her from the bottom of his heart. His strict oriental culture, which he raised, makes him not to accept such a relationship. Sahar Khalifa accuses the patriarchal society of being against Mariam. She is oppressed by their inherited traditions: "But the village and its traditions, her brothers, and people's conditions in this country and at this time required that a person be considerate and think of the others before oneself" (p. 78). Mariam became isolated. She does not want to interact with the society that oppressed her. She stopped appearing in the village, went to the market, or visited her friend Yvonne and the priest's house. Through Khalifeh's novels, the reader witnesses how Palestinian society maintains strict rules and values as part of preserving social traditions. Mariam, persecuted by her beloved Ibrahim, explains that she was a victim of harsh customs, because she told him about her previous love story. As is common in Palestinian society, Ibrahim refuses to have his lover in a relationship with a man before him. Khalifeh also reminds us of some stories that justify the oppression of women by honor. He represents the dominant and oppressed man in patriarchal society, who has the right to practice freely throughout his life. While preventing women from falling in love before her marriage. In addition, Mariam is in danger of her brothers. Her mother threatened that she would tell her brothers to kill her. Love's relationship with Ibrahim becomes serious when they learn about her pregnancy: "We were surprised by Mariam's pregnancy. All the pills to end the pregnancy failed, leaving us only one choice- abortion. But abortion required money that we didn't have" (p. 80).

Ibrahim asks his father for money to help Mariam abort and get rid of the child, but Mariam refuses his father's help. She does not want him to control her life by his money. She challenges the community and her family to do what she wants. Later, Ibrahim begins to suspect his fatherhood of Mariam's child. He asks himself whether 


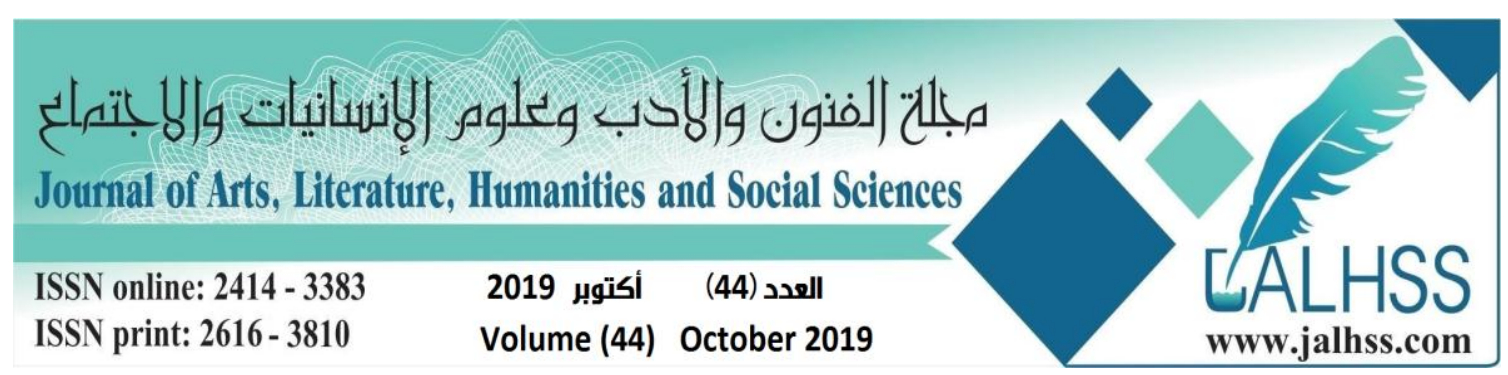

the child is his son or the priest's son and what proves this thing. He persecuted her of these doubts. Later, he began to repent:

Then there was Mariam's son was he really my son? Was he my flesh and blood? What proof did I have that I have that he was mine and not the son of the priest? What proof did I have that I was the father? (Khalifeh, 2005. P. 82).

This is Mariam's most severe repression. She is the real victim of patriarchy in her homeland and Brazil. In her daily life, Mariam knows that her family and traditional society are so cruel that they are not merciful. Her relationship with Ibrahim was a challenge to all traditions and customs in society, yet he abandoned her just because she was honest with him and told him about her previous relationship. He could not accept this relationship. He surrendered and left her facing her fate alone. He abandoned her when she needed him and was pregnant with his child.

Her mother discovers her love affairs. She knows about her pregnancy despite her weak vision. She's so cruel and tougher with her. Mariam is threatened again. She could not avoid the torment of her brothers. For her suffering, her brother came from Brazil. Their mother asked them to come to the scandal and deal with it. In traditional Palestinian beliefs, this is totally unacceptable. To her anger, the mother tries to punish her for justifying her response as a way to restore the family's spoiled honor for her daughter pregnant. Her life becomes more dangerous: "Mariam's brothers arrived seconds before the war started. They rushed to the village seeking a resolution for the scandal... they had come to save face and their dignity in a village waiting to see bloodshed" (p. 87).

The Patriarchate plays a crucial role in the torture of Mariam. She is the cause of an honor crime. This crime is an aspect of traditional patriarchal society: "honor killing is part of tradition, and only blood washes away the shame brought about by a girl" (p. 87). Mariam escaped to a safe place to protect her life. She chose a church to avoid being killed by her family. Through The Image, The Icon and the Covenant, Khalifeh expressed the Palestinian man's view of women via the protagonist's dialogues. They consider women as a kind of curse. They all time bring shame to their families. Women are not faithful like men and they the cause of the society's scandal: "By God, women are the biggest curse. They are brainless, stupid, and lack faith. If one of us is cursed with a baby girl, he should bury her alive and put an end to his worries" (p. 127).

Kahlifeh explains that the moral behavior of the Palestinian and Arab women are supervised and controlled by the men. The meaning of masculinity is to engage in daily practices, as the fundamental cause of which is to protect the honor of the women in their family. In Arab traditions, a man is that person whose women's honor is a social question for him. She has shown that it is a scandal in Arab tradition that a 


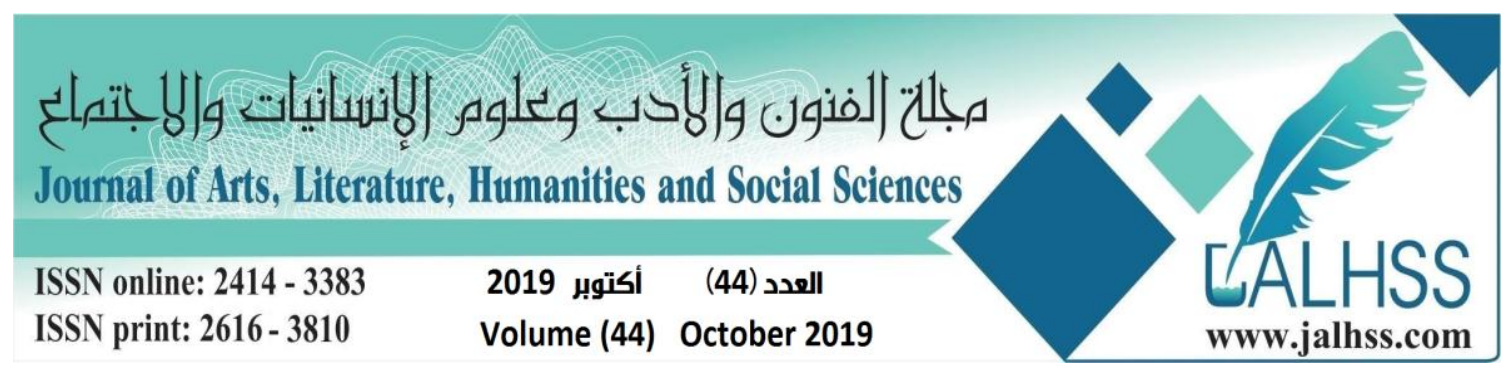

man does not avenge his loss of honor. If he does not avenge by killing his sister or wife as soon as she is disgraced, he bears the loss of his manhood and he is no longer a man in his community. Mariam leaves her family and hides in Jamileh's house, running away from killing of her brothers, the people in the village, and gossip. She delivered her baby in Jamileh's house. She decided to depend on herself and tried to find work to get rid of her sadness. She wanted to save her life by working. She discarded by her family. Therefore, she worked to earn her life's expenditure and depend on herself. She found a job in the Armenian photo shop store. She was able to pay rent for Jamileh regularly.

When Ibrahim returns, he tries to search for Mariam. In Jamileh's house he reads her memoirs. Jamileh told him about Mariam's story and her sufferings. Ibrahim becomes aware of her sufferings through her memoirs. These memoirs represent her dilemma in the patriarchal society. She suffered from isolation and oppression of all those around her: "I feel dizzy in this world, pressure is making my head explode, I am oppressed, the baby is getting on my nerves, loneliness is killing me" (p. 178). She describes her humanitarian work as a member in a library: "I took a membership in a nearby library, I take Arabic language lessons, the teacher says that I am the brightest of all the students" (p. 178). She tried to learn Arabic because she is weak in Arabic and wants to document her suffering. Mariam's behavior reveals her determination and ability to overcome her injustice and stands firmly against the habits of repression that violate her life and privacy. Despite the harshness of her situation, she never gives up, but she continues to build her life and tries to make the right decision. She tells her hardships and dangerous lives in her patriarchal society. This persecution deprived her of a sense of motherhood. The injustice suffered has negatively affected her motherhood and feels nothing but oppression: "They say that motherhood is miraculous, pure love, affection, sacrifice, devotion, and gratefulness, but I only feel oppression and revolt, I want to run away from my heart" (p. 197). She is dissatisfied with her circumstances. She got agitated. She could not know how to live her oppressed life:

But what about me, I thought? My needs and my deeds? Should I dance or write or look after the baby? I borrow books and return them, and I look for a job, but what do I want? What shall I do? (p. 180).

In the above lines, the level of suffering of Palestinian women who seem to be victims of the difficult patriarchal system directed at them is clear. The oppression and repression of Palestinian women via patriarchal values is an ongoing suffering that women often face with rebellion and the challenge that may lead to punishment or even death for violating patriarchy but sometimes they want to remain silent and isolated to protect their lives. 


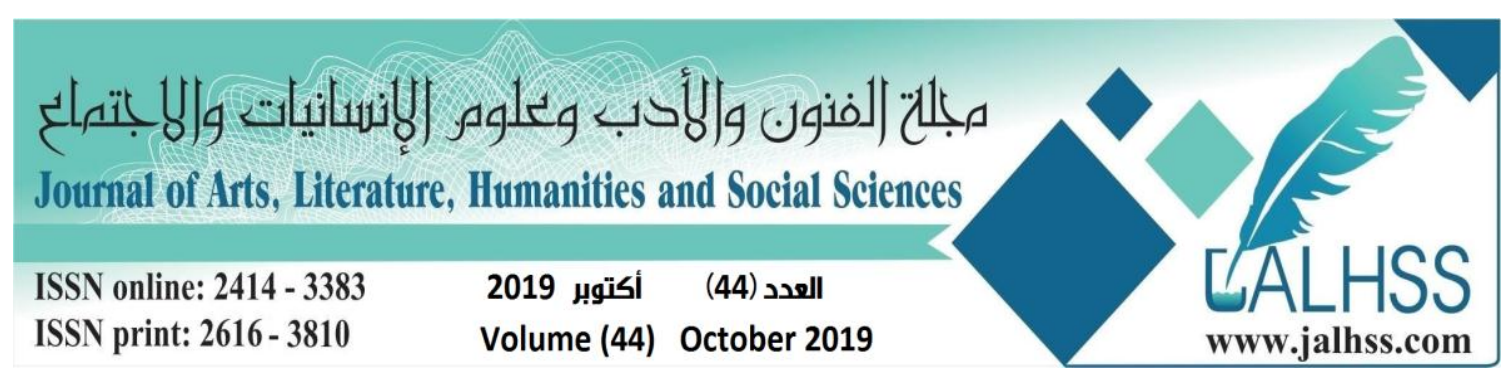

The diary of Mariam tells of her persecution of her community and family. This persecution made her live in isolation in the convent because she rejected this society which rejected her and caused her suffering. For her, submission to isolation and life in the convent is much better than a life full of isolation, humiliation, and sorrow with a traitor lover and a repressive society. According to Mariam, living alone is the only means available to her to get rid of all the restrictions and traditions that ruin her life and the tragedies she has experienced as a result of those traditions. She prefers a sense of loneliness, isolation and pain rather than a return to subjugation and submission to an unjust force imposed in respect for repressive society.

\section{Conclusion}

This paper has discussed women suffering in Khalifeh's The Image, The Icon and the Covenant. The argumentations of such suffering have pinpointed the masculine authority over women in the Palestinian society. The discussion relied on Lorber's (1994) arguments on the oppression of women and how they are challenged this oppression. In sum, the paper has concentrated on the oppressed woman and their various ways to challenge the oppressive and the authoritative masculine domination.

\section{References}

Farag, J. (2017). Politics and Palestinian literature in exile: Gender, aesthetics and resistance in the short story. London: I.B. Tauris; London Middle East Institute: SOAS, University of London.

Nassar, M. (2017). Brothers apart: Palestinian citizens of Israel and the Arab world. Stanford, Calif: Stanford University Press.

Criado, C. (2019). Invisible women. Data bias in a world designed for men. New York: Abrams, Inc.

Farrugia, M. (2019). The future is feminist: Radical, funny, and inspiring writing by women. San Francisco: Chronicle Books.

Manne, K. (2019). Down girl: The logic of misogyny. Oxford: Oxford university press.

Priyanka \& Koudur S. (2016) "Israeli Occupation and Palestinian Resistance in the Novel Wild Thorns by Sahar Khalifeh", with Priyanka as the first author in International Journal of Humanities and Cultural Studies, Vol. 3 (2).

Priyanka \& Koudur, S. (2018) "To Go or Not to Go: Palestinian Realities of Exile in the Works of Sahar Khalifeh", in Pertanika: Journal of Social Sciences and Humanities, 26 (1).

Priyanka \& Koudur S. (2018). "The Multiple Resistance Strategies for Survival under Israeli Occupation in the Novels of Sahar Khalifeh", in Khazar: Journal of Humanities Social Sciences, 21 (4).

Johnson, P (2007) "Palestinian Single Women: Agency, Choice, Responsibility" Review of Women's studies Vol 4. Birzeit: Birzeit University Press.

Lorber, J. (2012). Gender Inequality: Feminist Theories and Politics. Los Angeles, California: Roxbury. Pp. 73,119 